\title{
Implementation of Task-Based Language Teaching: To What Extent is Communicative Competence Achieved?
}

\author{
$1^{\text {st }}$ Ni Putu Somawati \\ Tourism Department \\ Politeknik Negeri Bali \\ Kuta Selatan, Badung, Bali, Indonesia \\ psomawati@yahoo.com
}

\author{
$2^{\text {nd }}$ I Nyoman Kanca \\ Tourism Department \\ Politeknik Negeri Bali \\ Kuta Selatan, Badung, Bali, Indonesia
}

\author{
$3^{\text {rd }}$ I Made Rai Jaya Widanta \\ Mechanical Engineering Department, \\ Politeknik Negeri Bali \\ Kuta Selatan, Badung, Bali, Indonesia
}

\begin{abstract}
This study was in attempt to recognize to what extent task-based language teaching (TBLT) effective to achieve learners' communicative competence $(\mathrm{CC}) . \mathrm{CC}$ is realized as a competence comprising two aspects, they are fluency and accuracy. Fluency is built up of three aspect of 'fluency', 'pronunciation', and 'comprehension', while accuracy comprises two aspect, they are 'grammar' and 'complexity'. Sixty two students of Tourism department from two classes were involved to be research participants whom were given pre-test, treatment, and post-test. The treatment was given for ten sessions using English for Tourism module designed with TBLT approach. Result of both tests were analyzed and compared to see how it was effective to the learners $\mathrm{CC}$ improvement. Results of discussion fostered that TBLT was effective for the improvement of learners, CC, especially that of fluency and one aspect of accuracy, i.e. 'complexity'. The further investigation should be undertaken to recognize why TBLT failed to improve learners' 'grammar'. In addition, it should be put in an attempt to see what technic should be affixed or developed to find a visible one for its solution.
\end{abstract}

Keywords-- task-based language teaching, communicative competence, grammar, effective.

\section{INTRODUCTION}

The learning of language ends at the achievement of communicative competence (CC). CC has been used as an indicator based on which ones' English mastery is measured. In spite of its fame to language learners, language educators, and linguists, it still receives contradictive idea on what aspect it includes. Krashen [1] proposes four major aspect of CC, they are linguistics, sociolinguistics, discourse, and strategic competence. Canale and Swain [2] introduces three aspects of $\mathrm{CC}$, such as grammatical, sociolinguistics, and strategic competence. A communication will be of much success if all the competence are fulfilled proportionally. A speaker of a language (e.g. English) is required to cope with the competence in order to perform appropriate utterance. Linguistic or grammar competence consisting of knowledge of language, lexical, semantic, as well as grammar plays an important role. Without fulfilment of rule, one's language production will sound awkward. Sociolinguistic competence which regulates the appropriateness in the application of a word and the way how aspects of language are used appropriately to make one's utterance polite also essential as language or speakers of the language have their own culture. The way how one should perform utterances in a communication (strategic competence) also an essential role to obey. This competence will determine whether or not one's utterance will become smooth and is able to avoid one of the communicative matters (e.g. communication breakdown) [3]. As Canale and Swain [2] stated, sociolnguistic competence is one of competences which also covers the so called pragmatic competence. Pragmatic competence is the ability to use language appropriately and effectively in a particular context [4-5]. Pragmatic competence comprises two main aspects, pragmalinguistic and sociopragmatic competence [6]. The aspect of pragmalinguistics as the linguistic end of pragmatic is that which rules how grammar should be orderly utilized to make an utterance appropriate. Thus, the form of language has to be used functionally [7].

Grammar, one of the aspects of $\mathrm{CC}$, holds a position which seems to be unreplaceable. Grammar will make the language work, since without its presence in speakers' utterances, they may sound ambiguous, does not work and go beyond. Even though grammar teaching is suggested to be undertaken implicitly in order for the learners not to be exposed to focus on forms rather than meaning which is opposed to the Richards and Rodger' [8] idea that learners shall be triggered to be fluent prior to be accurate at using English language, teaching grammar should also be carried out explicitly in some cases. Without an explicit teaching method learners will not be able to put in his or her mind the grammar point(s) of each lesson which is the basic treasure for him or her to construct sentences. Thus, it is important for learners to notice the input of forms to become intakes that is the utterances or sentences produced after listening inputs [9]. This is in line with the finding or work on teaching pragmatics aspect to vocational students undertaken by [10] that students have to be taught the forms of language (pragmalinguistic) explicitly in order for them to be able to realize its use in the form of sentence. This 
study was in purposes to investigate whether or not task-based language teaching (TBLT) is visible to improve learners' awareness of grammar or form.

\section{A. Related Study}

Ideas and opinion on the effectiveness of TBLT model for teaching languages was still contradictive one another. This is resulted by the condition that those studies used different focus, locus, goal, and participants. Sato [10] found that TBLT was not visible for Japanese learners of English whose focus was to master language forms. By doing the learning, they were in purpose to be able to construct well-structured English sentences and write grammatical sentences. Thus the model was found ineffective even though they were able to improve their communicative skill. To cope with their problems and need, learning models which are able to improve learners' ability to write grammatical sentences are required, such as grammar translation method (GTM), presentation practice production method (PPP), and test teach test method (TTT). These models were proven to benefit their endeavor of mastering grammar. This finding is consistent with the work carried out by Burton [11-13]. stating that GTM, PPP, and TTT were found a lot more effective to improve learners' performance in writing English sentences rather than TBLT. In contracts, those models, especially PPP, was recognized ineffective to improve learners' of English as Second Language (SLA) communicative performance. Hence, TBLT was found a lot effective [14-15]. With its characteristic, task activity in TBLT enable the involvement of language use, to be a center of learning which provide learners' using of English which prioritizes context [16-18], and [19].

The explicit teaching of grammar in applying TBLT is defied by Rahimpour [20] as it will not optimize learners' performance in doing tasks in target language. Activities should be designed in order for learners to improve their analytical skills, learners shall be integrated with a meaningful communicative activity with a goal oriented approach to solve problem. Thus, analytic syllabus which centers exposes students' activity to do task is necessarily needed. In addition to this, Prabhu [21] states that in case of procedural syllabus which focuses on forms or grammar, the learning should be canalized to the "focus of meaning", and forms can be taught unconsciously.

According to Dickinson [22], TBLT failed to be implemented in Japan as the learning of English in Japan did not meet the criteria of TBLT. TBLT is unsuitable for lowlevel learners [11] and [13]. As its spirit is to use English as much as possible through communication activities, low level students will face difficulty to realize it since their shortage of vocabulary mastery and lack of forms. The case potentially result in communication breakdown. TBLT also result in lack of language use as there is still little acquisition value obtained by such low level students [23]. This approach was also found less supportive to learners' language acquisition as it lacks of theoretical and empirical support [11-13]. When the beginners are introduced with the use of language without being introduced some comprehension on the target language (TL) as a foundation, such as forms or grammar, structure of sentences, and other basic theory of the TL in advance, they will face difficulty to use the TL. They will find themselves unconfident to use the TL considering their limited language sources. The in sufficient focus on form also result in the limitation of TL use [23], [12], [13].

In addition, Sato [10] and Sheen [12] further clarified that TBLT is unsuitable for EFL context as learners' immediate need is not to use English outside the classroom but to achieve academic achievement in the classroom instead. It is in line with the target of former English teaching in schools in Indonesia which was in the basis of grammar-oriented. TBL also deviates from learning style and expectation of Japanese learners. Historically, Japanese has been influenced by culture of Confucian heritage where teachers are supposed to have authority over students, EFL learners of Japanese are also still strongly coped with the doctrine that they hope to have grammar-centered approach [24]. The proof signalizes that TBLT demotivates Japanese learners as they intend to focus of preparing for exam [10].

\section{B. Concept}

\section{a. Task}

Breem [25], task is any effort of language learning which has specific objectives, appropriate content, procedure, and a range of outcome. Task is a range of plan of work with an overall goal of facilitating language learning in form of problem solving, discussion or simulation. The work plan requires learners to process language pragmatically in order to achieve an outcome evaluated in term of whether or not its goal instructed is achieved [14]. Ellis implies that a task has to have a plan which involves primary focus on meaning, real-world process of language use, any or the four language skills. In addition he notes that a task should engage cognitive process and has a clearly defined communication outcome. In line with Ellis' note, Willis and Willis [26] underscore that a task has to have a number of defining characteristics, such as engages the learners' interest, focuses primarily on meaning, measures a success in term of non-linguistic outcome rather than accurate use of language form, as well as relates to real world activities. This concept underlines that TBLT will be successful if the non-linguistic outcome such as whether or not the goal instructed is achieved by the learners. In this case, by doing the process and producing product learners are promoted with language learning [16].

\section{b. Task-Based Language Teaching}

Ellis [14] states that TBLT can be done with many ways. It is a context where tasks are the central unit of instruction which drives classroom activities, defines curriculum and syllabus as well as determines modes of assessment [16]. This approach is set to engage language learners' activities which are meaningful and goal-oriented to solve problems, complete project, and reach decision [27]. They clarify that TBLT should be implemented based on taskbased syllabus which is procedural, focuses on the learners' 
ability to perform target-like task without any explicit instruction of grammatical rule [27], [20]. Task-based syllabus should be specially designed to meet the need of its implementation for number of reasons, such as it needs to be compatible with the cognitive processes involved in second language acquisition, it can emphasize on learners' engagement in communication activities, and it can serve as a suitable unit for specifying learners' needs [14]. As TBLT prioritizes learners' involvement in communication activities to reach fluency which ignores accuracy [27] in order to meet the goal of task completion, it leaves question on how and when to concern with learners' mastery, it is important to design a task to be a well-designed one to activate and empower learners' noticing of TL or L2 syntax, vocabulary, and phonology that may lack perceptual and psychological saliency in untutored conversational settings and so may go unnoticed and unlearned [9], [27]. To embody this concept, grammar teaching should be undertaken explicitly in an unconscious process, as what had been tried by Prabhu [28] in Bangalore project of communication teaching.

Nunan [29] differentiates TBLT from traditional formfocused pedagogy in terms that TBLT copes with loose discourse structure and traditional form-focused instruction uses rigid discourse structure. TBLT enhances that learners are able to control topic development and the traditional method requires teacher to control topic development. In TBLT, the teacher does not know what the answer is as problem solving may always develop but in traditional way, teacher always know the answer. In TBLT, students' initiating and responding role as well as performing language function can develop more widely, in traditional pedagogy students' effort to do so is limited. TBLT energizes students to negotiate meaning and teachers' scaffolding functions to enable students to say what they want to say, but traditional pedagogy limits students' chance to negotiate meaning and scaffolding function to enable students to produce only correct sentences. Lastly, TBLT is content-focused feedback and the traditional method is formfocused feedback. The clear cut implies that TBLT, in its implementation, covers stages, such as scaffolding, task chains, recycling, organic learning, active learning, integration, reflection, and copying a creation.

\section{c. Realization of Communicative Competence in TBLT}

As clarified above, communicative competence (CC) comprises grammatical, strategic, and sociolinguistic competence [2], or grammatical, strategic, sociocultural, and discourse competence [30], or linguistic, strategic, sociocultural, actional, and discourse competence [31]. Apart from this clear cut, [1] proposed $\mathrm{CC}$ cover four major competences, such as linguistic, sociolinguistic, discourse, and strategic competence. Canale and Swain [2] further breaks down sociolinguistic competence into pragmatic competence. Leech [6] finally breakdowns it into two parts, they are pragmalinguistic and sociolinguistic competence. As the target of TBLT is to empower learners to utilize TL in communication as much as possible by implicitly learn the language forms. However, to foster learners' forms mastery they have to be exposed to forms learning. Even though it is not explicitly introduced, the attempt to include aspect of forms in scoring rubric will trigger teachers and earners to give attention to aspect of accuracy. Hence, the scoring rubric contains accuracy as a determining factors to judge one to be considered competent. To realize the endeavor, TBLT implementation includes the introduction of grammar part in some parts of every chapter or topic. Grammar part is also underlined in the section of task-based activity. The aspects accuracy is energized by measuring 'grammar' and 'complexity' and the aspect of fluency is empowered by measuring 'fluency', 'pronunciation', and 'comprehension' in the rubric.

TABle 1. The Realization of CC AsPeCts SCORED

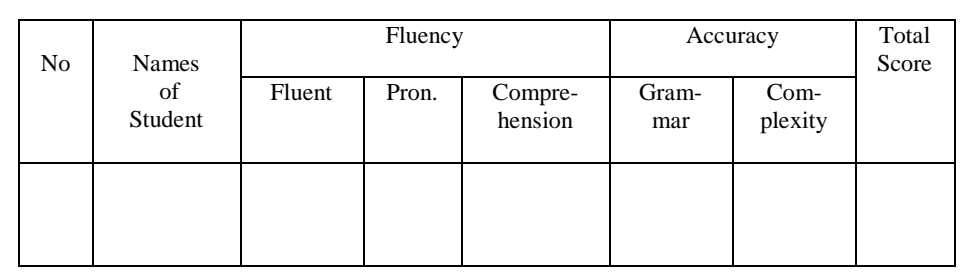

Note:

Scoring scales

Score 1 = Not fluent, incorrect pronunciation, not able to

Comprehend interlocutor's utterances, not accurate, are able to produce simple sentences.

Score 2 = Less fluent, less accurate pronunciation, show ability to comprehend interlocutor's utterances, not accurate, try to use more complex sentences.

Score 3 = Fluent, less mistake of pronunciation, able to comprehend interlocutors' utterances, fairly accurate, try to use complex sentences.

Score 4 = Fluent, accurate pronunciation, comprehend interlocutors' utterances, accurate, able to use complex sentences.

\section{RESEARCH METHOD}

This research involved 62 semester 2 students majoring in tourism as participant. The participants, 40 female and 20 male, come from 2 different classes. The participants are adult learners who get a 3-hour-session of English every week. There is no special rule put as a consideration based on which the subjects are chosen. The basic consideration is that because they are from the same age and level. Their basic level of English proficiency was not measured in advance. The researcher only used the information as a criteria that both groups of student have similar level of ability drawn with their final test result in their prior semester.

The instrument used to measure their basic English competence was a test designed to measure their prior and post treatment test. As the treatment used task-based English learning materials, the test was developed on the basis of the content of materials. The test was designed in form of an oral role play card containing a situation where learners had to perform utterances. Learners were paired up and given a card consisting of two roles, a local people and a visitor. A tourist 
was to ask a local person about things related to do and see in Bali. A local person was asked to make response.

You want to spend holiday in Bali during your campus holiday. You want to visit some places where you can see sun set, go surfing, shop or buy handicrafts. Say what you want to do there and ask a local person which place you should go to. Start like this: Excuse me, I want to ........ Are there any places where I can..............?

How may I help you?

Fig1. Role Play Card

Prior to its use, it was piloted by a two groups of student to see whether or not the card was valid to students. To do so, students were assigned to try performing dialog using the card and to give comment on the card, in term of language used, term written and its sentences length. Validation was also done by an expert. For that purpose, an expert in area of English teaching from one of state education universities in Bali who has been coping with validating such an instrument was assigned to comment on the card. Upon being given some comment, revision was then made to revise it.

Pre-test using the card was carried out in advance prior to the treatment. The test was undertaken for two days, the first day is for class A and the second day is for class B. In the pretest session, the English lecturer teaching those classes invite 15 couples to be given 7 minutes chance each to perform dialog pursuant to the card. Before giving the pre-test, the lecturer was trained on how to conduct the test and to score. The scoring sheet completed with scoring rubric was designed and prepared. There are two main sections tested, they are fluency and accuracy. Both of them were set in accordance with the aspects of communicative competence.

The score given to students' production is printed in the table above. There were 5 scores given to each student, divided into two parts, fluency and accuracy. The scores were based on 4 Likert scales. The scoring rubric was used for both test, pretest and post-test. Before the post-test administration, the students was given English learning using module of TBLT. The learning was given for 10 meetings before the students being tested with the same test. The result of pre-test and posttest were accumulated and analyzed using descriptive statistic.

\section{RESULT AND DISCUSSION}

TABle 2. Participants' SCORE OF PRE-Test

\begin{tabular}{|c|c|c|c|c|c|}
\hline & \multicolumn{5}{|c|}{ Pre-Test } \\
\hline & \multicolumn{3}{|c|}{ Fluency } & \multicolumn{2}{|c|}{ Accuracy } \\
\hline & Fluency & Pronunciation & Comprehension & Grammar & Complexity \\
\hline $\begin{array}{l}\text { Total } \\
\text { Score }\end{array}$ & 123 & 130 & 134 & 122 & 132 \\
\hline Average & 1,98 & 2,09 & 2,26 & 1,96 & 2,12 \\
\hline $\begin{array}{l}\text { Average } \\
\text { of } \\
\text { Fluency } \\
\text { and }\end{array}$ & \multicolumn{3}{|c|}{$\begin{array}{c}6,33 \\
(\text { Each Skill Average : 2,11) }\end{array}$} & \multicolumn{2}{|c|}{$\begin{array}{c}4,08 \\
\text { (Each Skill } \\
\text { Average: } 2,04)\end{array}$} \\
\hline
\end{tabular}

\begin{tabular}{|l|c|c|}
\hline Accuracy & & \\
\hline Total & 641 \\
Score & 10,23 \\
\hline Total & \\
Average & \\
\hline
\end{tabular}

Table 3. Participants' Score of Post-Test

\begin{tabular}{|c|c|c|c|c|c|}
\hline & \multicolumn{5}{|c|}{ Pre-Test } \\
\hline & \multicolumn{3}{|c|}{ Fluency } & \multicolumn{2}{|c|}{ Accuracy } \\
\hline & Fluency & Pronunciation & Comprehension & Grammar & Complexity \\
\hline $\begin{array}{l}\text { Total } \\
\text { Score }\end{array}$ & 145 & 165 & 187 & 141 & 167 \\
\hline Average & 2,35 & 2,66 & 3,01 & 2,27 & 2,70 \\
\hline $\begin{array}{l}\text { Average } \\
\text { of } \\
\text { Fluency } \\
\text { and } \\
\text { Accuracy }\end{array}$ & \multicolumn{3}{|c|}{$\begin{array}{c}8,02 \\
\text { (Each Skill Average: 2,94) }\end{array}$} & \multicolumn{2}{|c|}{$\begin{array}{c}4,97 \\
\text { (Each Skill } \\
\text { Average: } 2,48)\end{array}$} \\
\hline $\begin{array}{l}\text { Total } \\
\text { Score }\end{array}$ & \multicolumn{5}{|c|}{805} \\
\hline $\begin{array}{l}\text { Total } \\
\text { Average }\end{array}$ & \multicolumn{5}{|c|}{12,99} \\
\hline
\end{tabular}

It can be clearly seen that score of participants in the posttest outweighs that of pre-test, i.e. 805 being compared to 641 . The total average score of participants in post-test was 12.99 and their total average score of pre-test was 10.23. Their average score raised 2.76 upon their being given treatment with TBLT approach. There are five aspects based on which participants' competence was measured. Three aspects are under 'fluency' part and two aspects are included in 'accuracy' part. The pre-test results obviously show that participants' comprehension skill was the highest of all (134) followed by the complexity (132). Pronunciation was their third highest skill reaching 130 . Fluency seems to be easier skill to achieve (123) and grammar is the most difficult of all to be competent at (122).

The same case occurred to the result of participants' post-test. As can been clearly seen, comprehension was the skill which dominates other skills with the score 187. It raised significantly 53 points from 134 (in pre-test) to 187 (in posttest). The second highest skill was complexity with score 167 . It raised 35 points from 132 (in pre-test) to be 167 (in posttest). Pronunciation seems to be more difficult for the participants on both tests. In the post-test, their score only reached 165 which is 35 points higher than that in pre-test. This increase is considered significant. However, their increase in both 'complexity' and 'pronunciation' skill was the same (35 points) from pre-test to post-test. The forth skill of the participant on post-test was 'fluency' with 145. This skill increased only 22 points from pre-test to post-test. And the least skill of all was 'grammar' reaching only 141 score raising 19 points from 122 (in pre-test) to 141 (in post-test).

The same scene can be seen with the average score of the participants. Their highest average score of pre-test was obtained 2.26 for the 'comprehension' skill. Their average score for this skill increased only 75 points in post-test (to be 3.01). As the easiest skill, it increased very rapidly and to be the sharpest skill of all. This is the most skill participants achieved of all. The second skill which has significant 
increased on the participants upon their being given TBLT English learning was 'complexity' with an increase of 58 points from 2.12 (in pre-test) to 2.70 (in post-test). This skill achievement is almost similar to 'pronunciation' which increased 57 points from 2.09 (in pre-test) to 2.66 (in post-test). However, complexity still outweighs 1 point the 'pronunciation'. 'Fluency' places the forth rank with an increase of 37 points, from 1.98 (in pre-test) to 2.35 (in posttest). Its increase is slower that skills of 'complexity' and 'pronunciation' and a lot slower than 'comprehension'. The least skill to achieve was 'grammar' with an increase of 31 point from 1.96 (in pre-test) to 2.27 (in post-test). The data above helps us to note that the least skill to develop in participants is 'grammatical competence' and speaking, particularly 'fluency'.

In term of how 'fluency' and 'accuracy' domains developed in the participants upon the treatment with TBLT, the achieved scores showed an a bit flat increase. There was not such a great increase on participant achievement upon treatment. Their average score of 'fluency' and 'accuracy' domain of the pretest was 6.33 and 4.08. Those average score increased slightly to be 8.22 and 4.97 upon the treatment using TBLT model was carried out. In other words, participants' per-skill average score of fluency was 2.11 and that of accuracy was 2.04. It is clearly shown that participants' 'fluency' seemed still dominated their 'accuracy'. Their post-test result also showed the same scene where their 'fluency' and 'accuracy' scores were 8.22 and 4.97 respectively. And their per-skill average score was 2.94 and 2.48. This index shows that participants were generally foster 'fluency' skill better than 'accuracy' prior to and upon the treatment even though their scores of complexity in some cases placed higher position than other skill in domain of fluency.

The table above obviously notes that participants' 'fluency' score is higher than their 'accuracy'. This condition has been triggered by the fact that TBLT centralize the concept of communicative language teaching (CLT) where 'fluency' should be prioritized prior to 'accuracy' [8]. This achievement is also in line with the idea proposed by Seyyedi and Ismail [26] that goal-oriented learning is very useful for learners to improve their competence. Their desire to reach the goal is of much assistance for them to focus on an effort. Their target of improving English communicative skill attracted them to try hard. In addition, it is also supported with the concept of TBLT that is 'to complete project'. The concept always crosses in their mind that the learning will and certainly end(s) in realizing the project goal. The target had been motivating learner to work hard and they were unconsciously motivated to enrich their language property in order for them to be able to achieve the goal. Similarly, emphasizing the learners' engagement in communicative activities as proposed by Ellis [14] also took a part in the goal achieving. The teacher's effort to maximally engage the learners in communicative activities, for instance in doing task with pair or group work, force them to implicitly learn the language particularly in communicating their ideas and asking ideas, opinion, conclusion to member(s) of their group. This implicit learning of language has been a very effective way to improve their language skills.
This condition was also led by the implementation of learning syntax (lesson plan) which was designed to promote students' practicing the language. The lesson plan used to affix English learning using TBLT approach was LEAN, i.e. 'Lead in', 'Enrich', 'Activate' and 'Naturalizing'. 'Lead in' activity was designed to attract students' awareness of what is going to be learned in a certain session. In this occasion, students were led to focus their attention and thought to the topic of discussion. This stage was initiated by scaffolding with questioning technic. Students were asked some question related to the topic and were to give responses to those questions. This technic purely energized students' effort to communicate their ideas in English. 'Enriching' was also conducted with questioning technic. Although the purpose of the stage is to enrich students with forms, expression, structure of the sentences, as well as tense(s), questioning technic used in this stage attracts learners to practice using the language in communication. The forms learned were to be used in a conversation by trying to put them in a real-world context so that learners find the learning meaningful. "Activate" is the phase when learners do wider effort to practice the language by doing the task. The task, either done in pair or in group, provide them opportunity to practice a single language form. Each topic presents one task for the learners to work out. This chance certainly direct the learners to expand their ideas by creating more sentences or expressions in the form of questions or answer to maintain communication. The direction of the task that force them to extent conversation implicitly force them to maximize their present and prior knowledge to produce variety of sentences. Lastly, 'naturalization' stage also invite learners to practice their language learned and skill obtained in a wider range. This practice is freer than that in the former stage as they were directed to do a role play activity. This activity let learners express their language more freely without any pressure and border that they were able to be more productive. Since they did not have any psychological burden, they were able to produce variety of sentences. This is the concept what TBLT promotes which differs it with other traditional method, such, GTM, PPP and TTT [11-13].

The learners' 'fluency' was recognized higher than 'accuracy' (6.33 : 4.08 in pre-test and 8.02:4.97 in post-test) indicates that TBLT succeeded in improving their communicative competence, particularly that of 'fluency'. It implies that learner' goal, i.e. to be able to use the language for communication not only inside classroom but also in real life world [14-19]. Although, 'complexity' one part of accuracy aspect, was said to be the second best skill the learners achieved, but the total score of accuracy aspect was still found under that of fluency. It was certainly resulted by the fact that 'grammar' score downgraded it. In addition, grammar point was not taught, although in some case, it was exposed, explicitly in the learning. This is in line with the work of Rahimpour [20] that explicit grammar teaching will not optimize learners' performance in doing task in TL. Pursuant to the fact showed by the data, the success of TBLT in improving learners' grammar is still in question. In addition, 'grammar' score does not coincide 'complexity' score. This case should be brought in a further investigation to find out a solution for its 
response. Clearly, there should be a work to research why TBLT fail to improve both fluency and accuracy score. What technic has to be affixed in order for TBLT to be more visible and effective to improve not only leaners' fluency but also accuracy, even though earners are not focused on learning language in purpose to achieve academic achievement [10], [12].

\section{CONCLUSION}

The reality showing that TBLT was effective to improve students' CC was proven. It was triggered by the implementation of, one of them is LEAN learning model' a learning syntax comprising of Lead in, Encourage, Activate, Naturalization. This syntax is opposed to and responded the failure of TTT, GTM, PPP method which based on grammar teaching. Activate and Naturalization in the developed model promoted learners' activeness in using language in verbal interaction, especially Naturalization which triggered learners' production of utterances in real life situation. However, in the future research, the accuracy of the model shall certainly be proven by applying other aspects apart from this research, such as wider number of participants, different locus of focus, and so forth in order to find more visible result.

\section{ACKNOWLEDGMENT}

The author would like to thank Directorate Research and Social Service, Ministry of Research, Technology, and Higher Education for their financial support that this research was successfully undertaken.

\section{REFERENCES}

[1] Krashen, S.D. 1982. Principles and Practice in Second Language Acquisition. Oxford: Pergamond Press

[2] Canale \& Swain. 1980. Theoretical basis of communicative approach to second language teaching and testing, Applied Linguistics.

[3] Widanta, I.M.R.J. \& L. N. C. Handayani. 2011. The implementation of task

based language teaching (TBLT)at Politeknik Negeri Bali (PNB) Astrategic approach to improve students' implicit knowledge of English. Jurnal Sosial dan Humaniora (Soshum) PNB, vol 1 no 2, Juli 2011 (104 112).

[4] Timpe Laughlin, Wain, \& Schmidgall, 2015

[5] Suka Sanjaya. I N. 2017

[6] Leech, G. (1983). Principles of pragmatics. London: Longman

[7] Widanta, M.R.J. at all. 2016. Self-directed learning (SDL)-based learning center (LC): a strategy to improve students' TOEFL score. International Journal of Research in Sosial Science. 6.issue 2. 51-58. http://www.ijmra.us

[8] Richards, J. \& Rodgers, T.. 2001. Approaches and methods in language teaching. Cambridge: Cambridge University Press.

[9] Schmidt, R. 2001. Attention. In P. Robinson (Ed.). Cognition and second language instruction (pp. 3-32) Cambridge: Cambridge University Press.

[10] Sato, R. (2009) Suggestions for creating approaches suitable to the Japanese EFL environment. The Language Teacher, 33/9, 11-14.

[11] Bruton, A. (2002) From tasking purposes to purposing tasks. ELT Journal, $56 / 3,280-288$

[12] Sheen, R. (1994) A critical analysis of the advocacy of the task-based syllabus. TESOL Quarterly, 28/1, 127-151.

[13] Swan, M. (2005) Legislation by hypothesis: the case of task-based instruction. Applied Linguistics,26/3, 376-401.22

[14] Ellis, R.. 2003. Task-based language learning and teaching. Oxford: Oxford University Press.Estaire, S. \& Zanon, J.. 1994. Planning class work: A task-based approach. Oxford: Heinemann.

[15] Skehan, P.. 1996. Second Language Acquisition research and task-based instruction. In: Willis, J. \& Willis, D.. (Ed.). Challenge and change in language teaching. Oxford: Heinemann.

[16] Samuda, V. \& Bygate, M. (2008) Tasks in Second Language Learning. Houndmills: Palgrave Macmillan.

[17] Mackey, A. (1999) Input, interaction and second language development: an empirical study of question formation in ESL. Studies in Second Language Acquisition, 21/4, 557-589.

[18] Little, A. \& Fieldson, T. (2009) Form-focused tasks using semantically enhanced input. The Language Teacher, 33/3, 9-14.

[19] Takimoto, M. (2009) The effects of input-based tasks on the development of learners' pragmatic proficiency. Applied Linguistics,30/1, 1-25.

[20] Rahimpour, M. (2008). Implementation of task- based approaches to language teaching. Research on Foreign Languages Journal of Faculty of

Letters and Humanities, 41, 45-61.

[21] Prabhu, N. S. (1987). Second language pedagogy.Oxford: Oxford university press.

[22] Dickinson, P. 2010. The Implementation of Task-Based Languge

Teaching in Japanese EFL Context. Center for English Language Studies, the University of Brimingham, UK

[23] Sheedhouse, P. 1999. Task-Based Instruction. ELT Journal, 53 (3) 149156.

[24] Burrows, C. (2008) Socio-cultural barriers facing TBL in Japan. The Language Teacher, 32/8, 15-19.

[25] Breem, M. 1987. Laerner Contribution to Task Design. In. C. Candlin an D. Murphy (eds.) Language Learning Task (pp. 23-46) Englewood Cliff 5, N.J..: Prantice Hall.

[26] Willis, D \& Willis, J. (2007) Doing Task-Based Teaching. Oxford: Oxford

University Press.

[27] Syeyedi, K. Ismail, S.A.M.M. 2012. Task-Based Instruction International

Journal of Linguistics. Vol.4 no.3 pp.1984-5425. www.macrothink.org/ijl.

[28] Nunan, D.. 2005. Important tasks of English education: Asia-wide and beyond. Asian EFL Journal, 7(3).

[29] Calce-Murcia, Marianne, Z. Dornyei and S. Thurelll. 1995. "Communicative Competence: a Pedagogically Motivated Model with Content Specification” Issuses in applied linguistics, 6 (2): 5-35 